\title{
Microbial communities in the winter cover and the water column of an alpine lake: system connectivity and uncoupling
}

\author{
Marisol Felip*, Anton Wille, Birgit Sattler, Roland Psenner \\ Institut of Zoology and Limnology, University of Innsbruck, Technikerstr. 25, 6020 Innsbruck, Austria
}

\begin{abstract}
Active microbial communities formed by autotrophic and heterotrophic flagellates, ciliates and bacteria, inhabit slush layers of the ice and snow cover of high mountain lakes. Our study of the ice and snow cover of Gossenköllesee (Tyrolean Alps) during 2 complete winter periods, with special emphasis on the relationship between slush layers and the water column, confirms the hypothesis that the drastic changes in the physical and chemical structure of the cover determine biomass and composition of microbial assemblages. The temporal pattern previously described in the Pyrenees applies to the Alps, and we could distinguish 3 periods of winter cover: formation, growth and ablation. During the formation period (November to December), the ice sheet forms and slush layers start to develop. In the growth period (January to May), slush layer assemblages are mainly influenced by organisms deriving from lake plankton, predominantly flagellated chrysophytes, which peaked at different times and depths. During the ablation period (May to June/July), however, the cover assemblages are shaped by organisms and processes in the catchment. Microbial communities are characterized by the appearance of new species, such as Gymnodinium sp., red volvocales and large ciliates. The mutual influence between lake water and winter cover assemblages affects only the upper 1 to $2 \mathrm{~m}$ of the water column, while changes in the microbial composition of deeper water layers are slow and poorly related to slush layer assemblages. The appearance of ' 2 systems in 1 lake' is restricted to ca. $6 \mathrm{mo} \mathrm{yr}^{-1}$ and the reciprocal influence seems to be even more limited by space and time. During the ablation phase, i.e. when the influence of the catchment is much stronger than that of lake plankton, the slush microbial communities in the Alps and the Pyrenees are more similar to each other than during the growth phase of the cover. Over the whole winter period, the ice and snow cover appeared to be more dynamic, vertically variable and sporadically richer in biomass than the water column.
\end{abstract}

KEY WORDS: Phytoplankton $\cdot$ Bacteria $\cdot$ Protozoa $\cdot$ Slush $\cdot$ High-mountain lake

\section{INTRODUCTION}

High mountain lakes are covered by ice and snow for extended periods each year. The winter cover plays a major role in determining the environmental properties and the dynamics of the pelagic system (Reynolds 1984, Spaulding et al. 1993). It reduces heat exchange,

${ }^{*}$ Present address: Departament d'Ecologia, Universitat de Barcelona, Avinguda Diagonal 645, 08028 Barcelona, Spain. E-mail: marisol@bio.ub.es prevents turbulence generated by wind, reduces light penetration, and hinders the transfer of gases, liquids and particles between the atmosphere and the lake (Catalan 1992, Wharton et al. 1993). The cover itself is a complex physical structure, in which layers of snow, white ice and slush (mixture of snow and water) alternate on top of a sheet of black ice (Eppacher 1966, Adams \& Allan 1987). Episodic processes of flooding by lake water, melting and freezing, convert the cover into a dynamic environment with continuous changes in its physical structure and chemical characteristics 
(Catalan 1989). The presence of highly active microbial communities in the slush layers of the winter cover has been described in high mountain lakes of the Pyrenees and the Alps (Felip et al. 1995). Bacteria and many taxa of autotrophic and heterotrophic flagellates and ciliates inhabit slush layers and pools produced on top of the winter cover during late spring. These assemblages have been termed LIMCOs (lake ice microbial communities) on the analogy of sea ice microbial community (SIMCO, Sullivan \& Palmisano 1984), although in alpine lakes, microbial assemblages are not directly associated to the solid phase of the ice as it occurs in sea ice or in permanently ice covered lakes in Antarctica (Priscu et al. 1998, Psenner \& Sattler 1998). A detailed study in Lake Redó (Pyrenees) showed that temporal changes in microbial assemblages were strongly affected by the physical transformation of the lake cover and the snowpack in the catchment (Felip et al. 1999). After an initial phase, during which the ice sheet formed and the snow started to accumulate, with little or no development of slush layers (formation period), there were 2 stages of microbial assemblages, which coincided with the 2 main phases in the physical changes of the cover, i.e. the growth and the ablation period. Slush microbial assemblages originate from the phytoplankton-rich surface water that floods the cover due to hydrostatic adjustment. Subsequently, mixotrophic or heterotrophic flagellates grow and peak at different depths and times. During ablation, the rate of change in the species composition of the cover was higher and microbial assemblages were characterized by the vertical segregation and by the appearance of new species, some of which were typically non-planktonic. During this time, the cover is influenced by the large amount of melting water coming from the snowpack in the catchment. While this pattern seems to be typical for Lake Redó in the Pyrenees, and some aspects have also been observed in Gossenköllesee (i.e. bacterial biomass distribution in the slush; Wille 1996, Wille et al. 2000), we do not know, how general it is for high altitude or high latitude lakes. The Pyrenean winter, with alternating periods of high radiation and strong storms, induces a cover metamorphosis that is quite different from those at higher latitudes (Camarero 1994). To understand the driving forces and the main factors shaping slush layer communities, it is necessary to follow the temporal changes of slush microbial assemblages in lakes situated at different latitudes and being subject to other climate or weather conditions.

The study done in Lake Redó showed the mutual influence, in terms of physics, chemistry and biology, between surface lake water and slush layers. A fact which is principally also true for Gossenköllesee (Wille 1996), although both lakes differ enormously in size and depth (Felip et al. 1995). Little is known, however, about the relationship with deeper layers of the water column. In relatively shallow lakes, such as Gossenköllesee with a mean depth of $4.7 \mathrm{~m}$, the snow and ice cover can amount to up to $1 / 3$ of the whole lake water volume (Psenner et al. 1999, Wille 1996). In such cases, the cover assemblages may influence the whole water column, an aspect that merits further investigation.

The main objectives of this paper are 3-fold: (1) to track the spatio-temporal changes of microbial assemblages in the slush layers of the winter cover of Gossenköllesee and to discuss the results with those previously described in the Pyrenees looking for a general pattern; $(2)$ to describe the interactions between cover and water column assemblages throughout the winter; and (3) to derive a working hypothesis for the dynamics and interactions between water column, winter cover and catchment for lakes in snowy regions.

\section{MATERIALS AND METHODS}

Study site and measurements. The study was conducted in Gossenköllesee, an oligotrophic high mountain lake located at $2417 \mathrm{~m}$ a.s.l. (above sea level) in the Tyrolean Alps ( $\left.47^{\circ} 13^{\prime} \mathrm{N}, 11^{\circ} 01^{\prime} \mathrm{E}\right)$. It is a small (1.7 ha) and shallow lake (max. depth $9.9 \mathrm{~m}$ ) that is usually covered by ice and snow for more than $7 \mathrm{mo} \mathrm{yr}^{-1}$. More detailed information of its limnological features is published elsewhere (Felip et al. 1995, Sommaruga \& Psenner 1997, Wille et al. 1999, Thies et al. 2000).

The snow and ice cover and lake water column were sampled in the central area of the lake during the winters of 1996/1997 and 1997/1998. Samples were taken at 1 to $6 \mathrm{wk}$ intervals from the time the lake froze until the cover had completely melted (Table 1). Samples from the solid and the liquid phase of the cover (i.e. water from the slush layers) were obtained separately. An integral ice core was taken to characterize the solid phase and the stratigraphical structure of the cover. Slush water was directly pumped from each layer through small holes drilled in the cover by means of a special device consisting of a stainless steel pipe with an inner teflon tube. Lake water samples were obtained throughout the water column at 1 to $3 \mathrm{~m}$ intervals using a 51 Schindler Patallas sampler. The parameters considered in this paper include chlorophyll a (chl a) concentration, bacterial densities and biomass, and species composition and biomass of algae, heterotrophic flagellates and ciliates in slush layers and lake water samples. For these purposes, immediately after sampling, a set of subsamples $(100 \mathrm{ml})$ was fixed with formalin (final conc. $4 \% \mathrm{v} / \mathrm{v}$ ) to determine bacteria abundance, morphology and biomass. Another subsample $(500 \mathrm{ml})$ was preserved with 
Table 1. Sampling dates and physical characteristics of the winter cover. Hydrostatic water level (HWL) and depths of the slush layers are referenced to the top of the cover

\begin{tabular}{|c|c|c|c|}
\hline Date & $\begin{array}{l}\text { Cover } \\
\text { thickness } \\
(\mathrm{cm})\end{array}$ & $\begin{array}{l}\text { HWL } \\
(\mathrm{cm})\end{array}$ & $\begin{array}{l}\text { Location depth } \\
\text { of slush layers } \\
(\mathrm{cm})\end{array}$ \\
\hline 15 Nov 96 & 30 & 5 & - \\
\hline 13 Dec 96 & 40 & 7.5 & - \\
\hline 29 Jan 97 & 83 & 35 & 40 \\
\hline 13 Feb 97 & 88 & 38 & 40,58 \\
\hline 20 Feb 97 & 81 & 29 & 32 \\
\hline 5 Mar 97 & 79 & 23 & 28,61 \\
\hline 19 Mar 97 & 132 & 35 & 45,65 \\
\hline 2 Apr 97 & 118 & 19 & $29,64,79$ \\
\hline 17 Apr 97 & 162 & 22 & $32,87,122$ \\
\hline 1 May 97 & 167 & 21 & $71,91,111,121$ \\
\hline 15 May 97 & 194 & 32 & Pool, 42, 52, 80, 102, 142 \\
\hline 29 May 97 & 190 & 29 & Pool, 79, 106, 114 \\
\hline 5 Jun 97 & 110 & 6 & Pool, 35, 60, 75 \\
\hline 11 Jun 97 & 50 & 3 & Pool, 40 \\
\hline 19 Jun 97 & 44 & 0 & Pool \\
\hline 25 Jun 97 & 34 & 0 & Pool \\
\hline 7 Jul 97 & 0 & 0 & - \\
\hline 20 Nov 97 & 10 & 10 & - \\
\hline 18 Dec 97 & 65 & 35 & 54 \\
\hline 28 Jan 98 & 100 & 28 & 65,91 \\
\hline 19 Feb 98 & 89 & 25 & 50,76 \\
\hline 1 Apr 98 & 122 & 9 & $37,57,85,111$ \\
\hline 29 Apr 98 & 114 & 24 & $32,52,80,106$ \\
\hline 7 May 98 & 140 & 15 & Pool, 37, 56, 76, 115 \\
\hline 20 May 98 & 47 & 6 & Pool, 21, 34 \\
\hline 9 Jun 98 & 25 & 5 & Pool, 14 \\
\hline 21 Jun 98 & 0 & 0 & - \\
\hline
\end{tabular}

Lugol's solution to determine algal and protozoan abundances and biomass. A third subsample (1000 to $2000 \mathrm{ml}$ ) was filtered through glass fiber filters (GFF Whatman) for pigment analysis. Fixed samples were stored at $4^{\circ} \mathrm{C}$ and pigment filters were kept frozen until further processing.

Absorbance spectra of photosynthetic pigment extracts in $90 \%$ acetone were used to determine chl a concentration (Jeffrey \& Humphrey 1975). Bacterial abundance was determined by epifluorescence microscopy using DAPI staining on black membrane filters (Poretics, pore size $0.2 \mu \mathrm{m}$ ) following the method of Porter \& Feig (1980). Bacterial cell volumes and shapes were determined with an image analysis system (LUCIA, Laboratory Imaging) as described by LofererKrößbacher et al. (1998). Cell volumes ( $V$ ) were transformed into bacterial biomass $(C)$ using the allometric equation proposed by Norland (1993). Abundances of algae, heterotrophic flagellates, and ciliates were estimated with the Utermöhl method (Sournia 1978). To enumerate organisms that strongly differ in size and abundance, sedimentation chambers were screened at 3 different magnifications (150, 300 and 600×). While species identification were done at $1500 \times$ magnification. Biovolume was estimated by shape assimilation to known geometric forms and direct measurement of the main cell dimensions. If size differences were observed within a species, the individual cells were divided into several size classes $(<10$, between 10 to 20 and $>20 \mu \mathrm{m}$ ) in order to evaluate their biovolume more accurately. Size was converted into carbon according

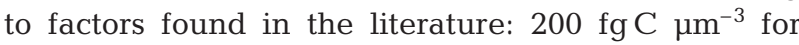
phytoplankton (Margalef 1983, Mullin et al. 1996);

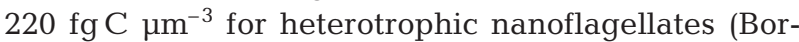

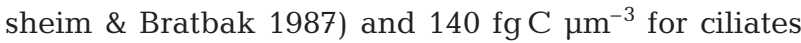
(Müller \& Geller 1993).

Data analysis. To analyze the resemblance between samples, 2 statistical approaches were used: calculation of the association matrix using a similarity coefficient and application of ordination techniques.

Similarity $(S)$ between samples was estimated using the coefficient proposed by Steinhaus, which is the best known to be used with raw species abundances (Legendre \& Legendre 1998). This coefficient compares 2 samples in terms of the minimum abundance of each species. The similarity was transformed into the corresponding distance $(D)$ by computing the square root of its one complement, $D=(1-\mathrm{S})^{1 / 2}$.

A multivariate statistical technique, correspondence analysis (CA), was used for ordination of species assemblages (ter Braak 1995). The analysis was performed with the biovolume of algal, heterotrophic flagellate and ciliate species which constituted more than $1 \%$ of the total biovolume in at least 1 sample (total 47 species). Species biovolumes were log-transformed because of their skewed distribution.

\section{RESULTS}

In both years, the lake froze in November and the ice and snow cover persisted until June or July (Table 1). Initially, a 5 to $10 \mathrm{~cm}$ black ice sheet quickly formed. Episodic snowfalls and concurrent flooding as a result of hydrostatic adjustment increased the cover thickness until mid-May, when melting started (Table 1). Different layers of slush were identified from December or January to the beginning of June (Table 1). Indicated by the changes of the thickness and physical structure of the winter cover, 3 periods could be recognized: formation (November and December), growth (from January to mid-May) and ablation (from mid-May to ice-out in June or July). During the ablation period, several meltwater pools developed on the cover surface. Such pools can be considered a particular habitat and will be treated separately in an upcoming manuscript. In this paper, pools assemblages composition will be indicated but samples will not be considered in further analysis. 


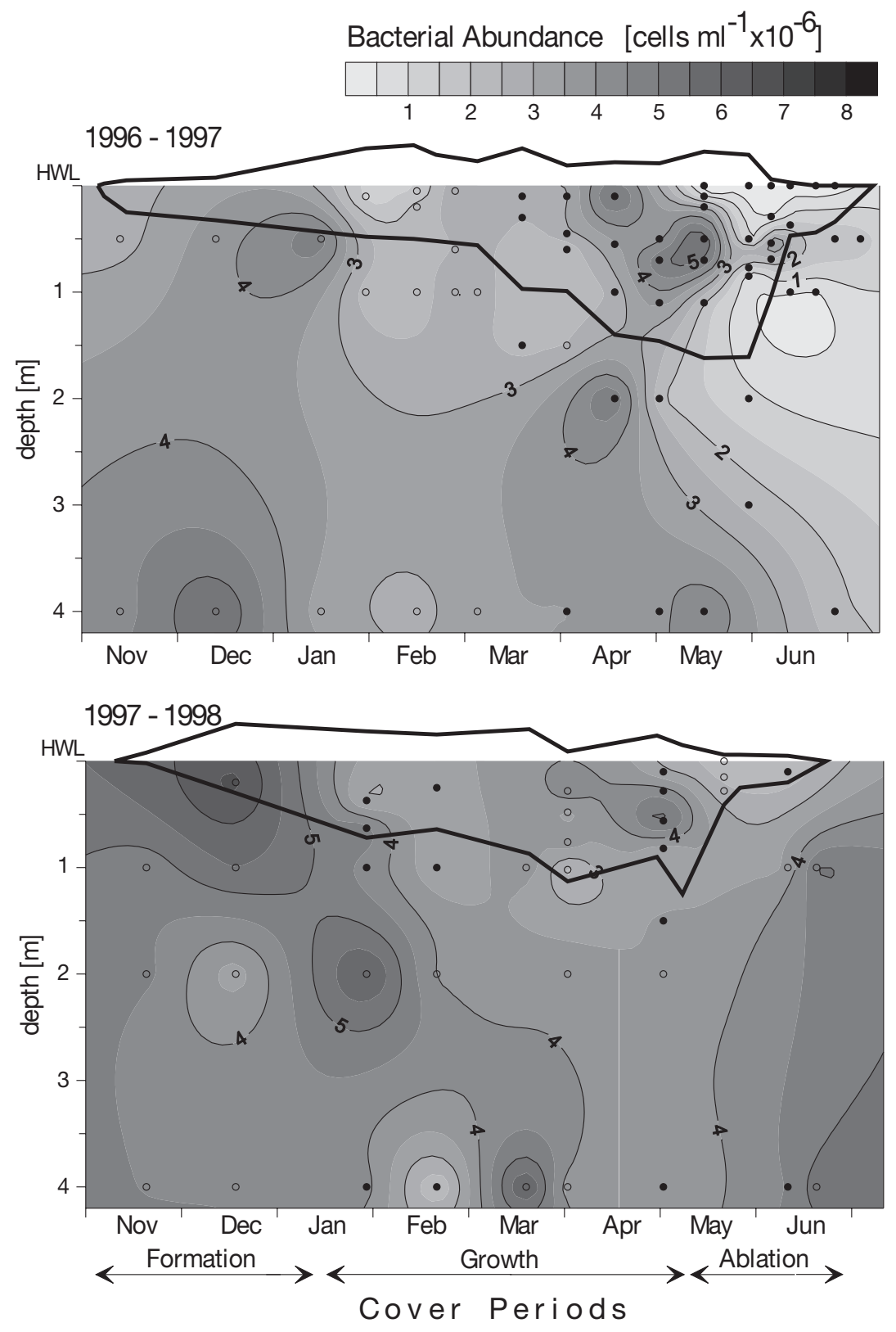

Fig. 1. Temporal changes of bacterial abundance in the slush layers of the winter cover and the upper part of the water column of Gossenköllesse during the 1997 and 1998 winter periods. The winter cover is represented by the bold line above and below the depth of $0 \mathrm{~m}$, which correspond to the hydrostatic water level (HWL). All slush layers were located below that level, which conforms to the painted border. Small circles: sampling points; closed circles: samples relevant for statistical analysis; open circles: all samples with bacteria data available. The 3 periods recognized in the temporal changes of the physical structure of the cover are also marked

\section{Composition and development of microbial assemblages}

Bacterial abundance ranged from 0.3 to $6.5 \times 10^{5}$ cells $\mathrm{ml}^{-1}$ in the slush layers and from 0.5 to $6.2 \times 10^{5}$ cells $\mathrm{ml}^{-1}$ in the lake water. The general pattern of the distribution of bacterial abundance over time and at different depths was similar in both winter seasons (Fig. 1). Values, in both lake water and slush layers, were initially high and decreased throughout the winter period with a restricted increase observed in the cover from March to May. Minimum values were measured during May when the winter cover reached its maximum thickness. In 1998, the melting of the cover was accompanied by an increase in bacterial abundance in the water column $\left(5 \times 10^{5}\right.$ cells $\left.\mathrm{ml}^{-1}\right)$. Small freeliving forms, short rods and cocci dominated the bacterial community. In the slush layers together with these small cells, long thin filaments (>50 $\mu$ m cell length) also appeared.

About 70 eukaryotic species were identified in the Lugol fixed samples from the water column and from the slush layers. Table 2 lists the main species encountered, which were considered in the statistical analysis because they constituted more than $1 \%$ of the total biovolume in at least 1 sample. Small autotrophic flagellated chrysophytes (Chromulina and Ochromonas sp.) were the most abundant species. Although they appeared in almost all samples of the winter cover and the lake water, maximum densities of these 2 species were always observed in slush layers. On the contrary, the diatom Cyclotella cf. gordonensis dominated lake water samples at high abundances. Some dinoflagellates (Gymnodinium sp.) and volvocales (Chlamydomonas sp.) were occasionally of some significance in the slush samples, whereas Pteromonas sp. and Chlamydomonas nivalis reached their maximum densities in superficial pools. Rhodomonas minuta, the most abundant cryptophycean species, reached its maximum density in lake water. Several forms or species of heterotrophic flagellates were found; the diversity within the group, however, is difficult to evaluate due to taxonomic problems. Chrysophytes were the main group among heterotrophic flagellates and high abundances were observed in slush layers at the end 
Table 2. List of the main microbial species identified in the winter cover and lake water samples. Freq. = frequency in samples $(\%)$, and Max. = maximum abundance (ind. $\mathrm{ml}^{-1}$ ), measured during 1997 and 1998 winter periods. The date and the place where Max. were measured are also indicated $(\mathrm{S}=$ slush, $\mathrm{P}=$ pool, $\mathrm{L}=$ lake)

\begin{tabular}{|c|c|c|c|c|c|c|c|}
\hline \multirow{2}{*}{ PHYTOPLANKTOI } & & 1997 & Freq. Max. & \multicolumn{3}{|c|}{1998} & \\
\hline & & & & & & & \\
\hline Chlorophyta & & & & & & & \\
\hline Volvocales & Chlamydomonas sp.1 & 26 & 68 & (15 May, P) & 18 & 6 & (9 Jun, S) \\
\hline & Chlamydomonas sp.3 & 40 & 290 & (5 Jun, S) & 9 & 1 & (20 May, S) \\
\hline & Chlamydomonas sp.4 & 56 & 317 & (5 Jun, S) & 23 & 43 & (9 Jun, S) \\
\hline & Chlamydomonas sp. 5 & 33 & 17 & (19 Jun, P) & 50 & 3 & (19 Feb, L) \\
\hline & Chlamydomonas nivalis & 23 & 47 & (19 Jun, P) & 14 & 2 & $(20$ May, $\mathrm{P})$ \\
\hline & Pteromonas sp. & 37 & 450 & (19 Jun, P) & 50 & 21 & (20 May, $\mathrm{P})$ \\
\hline & Non-identified species & 12 & 28 & (15 May, S) & 14 & 17 & (29 Apr, S) \\
\hline Desmidiales & Cosmarium sp. & 9 & 3 & (29 May, L) & 59 & 13 & (28 Jan, L) \\
\hline Chrysophyceae & Chromulina - Ochromonas spp. $3 \mu \mathrm{m}$ & 100 & 20306 & $(1 \mathrm{May}, \mathrm{S})$ & 91 & 2220 & $(19 \mathrm{Feb}, \mathrm{S})$ \\
\hline & Chromulina - Ochromonas spp. $5 \mu \mathrm{m}$ & 100 & 238 & (15 May, S) & 91 & 4364 & $(28 \mathrm{Jan}, \mathrm{S})$ \\
\hline & Chromulina - Ochromonas spp. $7 \mu \mathrm{m}$ & 72 & 35 & (19 Jun, L) & 91 & 68 & $(19$ Feb, S) \\
\hline & Chromulina - Ochromonas spp. $10 \mu \mathrm{m}$ & 47 & 20 & (11 Jun, S) & 55 & 10 & $(19 \mathrm{Feb}, \mathrm{S})$ \\
\hline Bacillariophyceae & Cyclotella cf. Gordonensis & 86 & 2497 & (13 Dec, L) & 91 & 7908 & (28 Jan, L) \\
\hline & Cyclotella distinguenda & 26 & 7 & (13 Dec, L) & 86 & 75 & (28 Jan, L) \\
\hline & Fragilaria sp. & 5 & 3 & (7 Jul, L) & 45 & 30 & (28 Jan, L) \\
\hline Cryptophyta & Chroomonas sp. & 28 & 22 & (5 Jun, L) & 14 & 29 & (9 Jun, S) \\
\hline & Cryptomonas marsonii & 9 & 12 & (29 May, L) & 50 & 11 & (7 May, L) \\
\hline & Cryptomonas cf. ovata & 35 & 5 & $(2 \mathrm{Apr}, \mathrm{S})$ & 59 & 24 & $(19 \mathrm{Feb}, \mathrm{S})$ \\
\hline & Rhodomonas lacustris & 28 & 10 & (1 May, S) & 41 & 12 & (29 Apr, S) \\
\hline & Rhodomonas minuta & 23 & 52 & (11 Jun, L) & 23 & 179 & (20 May, L) \\
\hline Dinophyta & Amphidinium elenkinii & 12 & 19 & (7 Jul, L) & 32 & 20 & (9 Jun, S) \\
\hline & Gymnodinium uberrimum & 30 & 1 & (11 Jun, L) & 55 & 2 & (7 May, S) \\
\hline & Gymnodinium sp. Small & 74 & 158 & (17 Apr, S) & 86 & 39 & (20 May, S) \\
\hline & Gymnodinium sp. Medium & 81 & 317 & (5 Jun, S) & 82 & 48 & $(19$ Feb, S) \\
\hline & Gymnodinium sp. Large & 40 & 155 & (15 May, S) & 45 & 33 & (29 Apr, S) \\
\hline & Woloszynskia cf. ordinata & 7 & 1 & (5 Jun, L) & 9 & 5 & (29 Apr, S) \\
\hline & Woloszynskia sp. & 9 & 2 & (19 Mar, L) & 23 & 2 & (19 Feb, L) \\
\hline HETEROTROPHIC & LAGELLATES & & & & & & \\
\hline Chrysophyceae & Spumella - Oikomonas spp. $3 \mu \mathrm{m}$ & 91 & 91 & (2 Apr, S) & 77 & 56 & $(19$ Feb, S) \\
\hline & Spumella - Oikomonas spp. $5 \mu \mathrm{m}$ & 86 & 1018 & $(2 \mathrm{Apr}, \mathrm{S})$ & 86 & 44 & $(19$ Feb, S) \\
\hline & Spumella-Oikomonas spp. $10 \mu \mathrm{m}$ & 37 & 6 & (2 Apr, S) & 32 & 1 & (29 Apr, S) \\
\hline Choanoflagellates & Monosiga ovata & 28 & 6 & (29 May, L) & 64 & 261 & $(19$ Feb, S) \\
\hline Cryptomonads & Goniomonas truncata & 26 & 12 & (15 May, S) & 23 & 13 & (19 Feb, L) \\
\hline Non-identified & Non-identified species 1 & 42 & 23 & (17 Apr, L) & 50 & 149 & $(28 \mathrm{Jan}, \mathrm{S})$ \\
\hline flagellates & Non-identified species 2 & 7 & 1 & (1 May, S) & 68 & 124 & $(28 \mathrm{Jan}, \mathrm{S})$ \\
\hline & Non-identified species 3 & 26 & 23 & (7 Jul, L) & 27 & 7 & (20 May, L) \\
\hline & Non-identified species 4 & 30 & 27 & (29 May, L) & 55 & 50 & (9 Jun, L) \\
\hline & Non-identified species 6 & 9 & 2 & (1 May, S) & & & \\
\hline CILIATES & & & & & & & \\
\hline Prostomatida & Urotricha sp. 1 & 5 & 0.08 & (17 Apr, S) & 14 & 2 & (9 Jun, S) \\
\hline & Urotricha sp. 2 & 21 & 3 & (19 Jun, L) & 9 & 51 & (9 Jun, S) \\
\hline Gymnostomatida & Askenasia sp. & 19 & 0.45 & (11 Jun, L) & 32 & 0.30 & (29 Apr, L) \\
\hline & Trachelius ovum & 5 & 0.03 & (1 May, S) & 5 & 0.03 & (9 Jun, S) \\
\hline Hymenostomata & Paramecium cf. putrinum & 33 & 0.30 & (1 May, S) & 27 & 0.07 & (19 Feb, S) \\
\hline & Non-identified species & 26 & 0.33 & (2 Apr, S) & 32 & 0.17 & $(19$ Feb, S) \\
\hline Oligotrichida & Halteria grandinella & 51 & 0.83 & (11 Jun, L) & 73 & 1.22 & $(19$ Feb, S) \\
\hline Suctoria & Non-identified species & 7 & 0.33 & (2 Apr, S) & 5 & 0.01 & $(19$ Feb, S) \\
\hline Non-identified & Non-identified species 1 & 21 & 0.13 & (1 May, L) & 23 & 0.08 & (29 Apr, S) \\
\hline ciliates & Non-identified species 2 & 12 & 0.05 & (19 Mar, L) & 23 & 0.40 & $(28 \mathrm{Jan}, \mathrm{L})$ \\
\hline
\end{tabular}




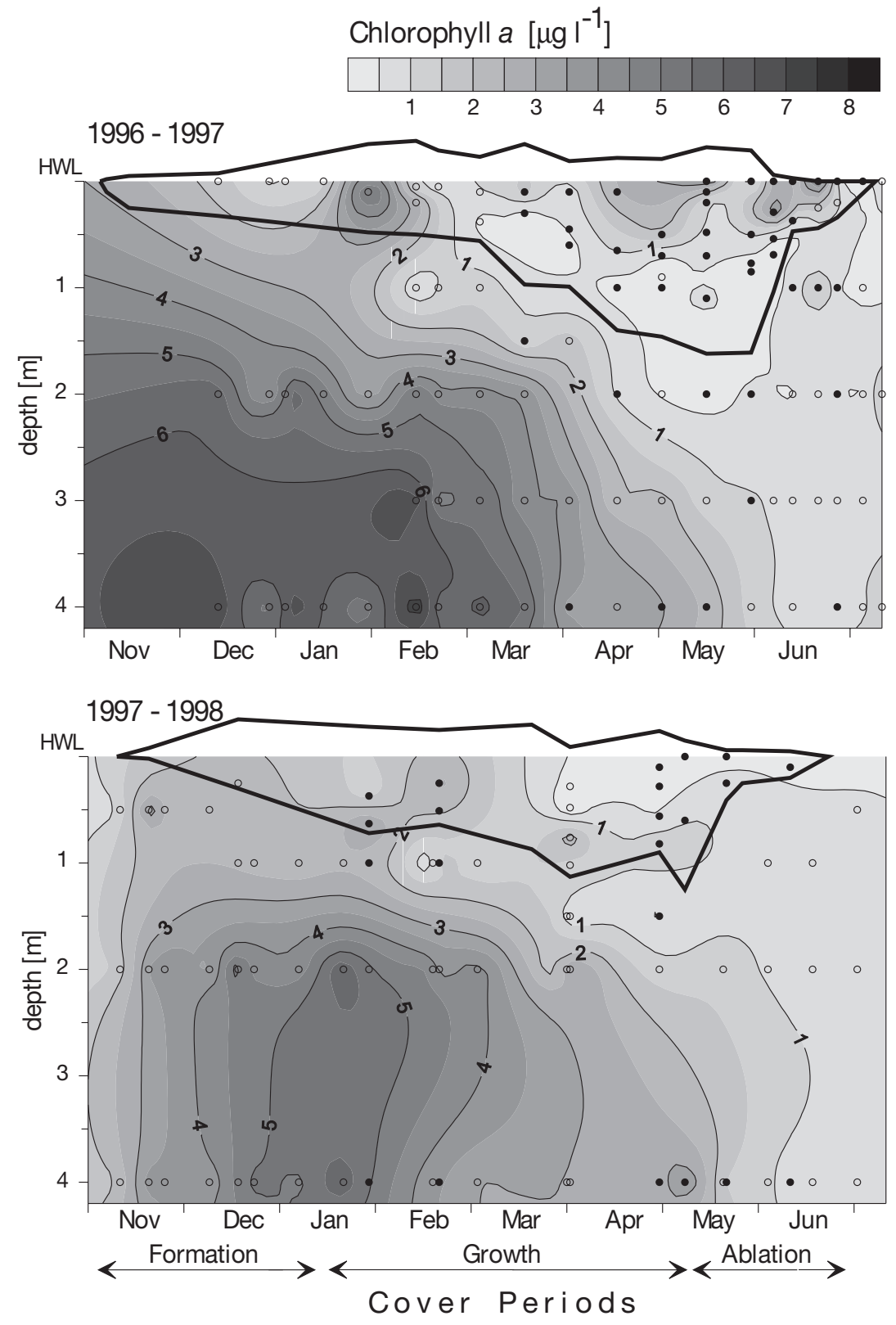

Fig. 2. Temporal changes of chlorophyll a concentrations in the slush layers and the upper part of the water column of Gossenköllesee during the 1997 and 1998 winter periods. Legend and map interpretation as in Fig. 1

high (>6 $\mu \mathrm{g}$ chl a $\mathrm{l}^{-1}$ ) and decreased throughout the winter period. At the beginning of the winter cover growth phase (February), chl a contents in slush layers reached high values (up to

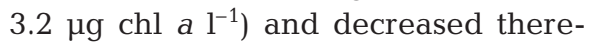
after. Minimum values were measured during April and May. In 1997, a long lasting ablation phase enabled blooming of algae in the upper slush layers leading to chl a contents of up to $4.3 \mathrm{\mu g} \mathrm{l}^{-1}$ (Fig. 2).

The development of phytoplankton biomass, indicated by the concentration of chl a (Fig. 2), was related to changes in the dominance of different taxonomic groups. During the formation phase, phytoplankton assemblages of the water column were dominated by diatoms, which represented on average $44 \%$ of phytoplankton biovolume in lake water samples. Diatoms, however, were poorly represented in the ice and snow cover (Table 3). On the other hand, chrysophytes and cryptophytes were more abundant during the growth period, where both biovolume and percentage distribution were similar in lake water and slush layers. Dinoflagellates dominated the assemblages during ablation and showed higher biovolumes (absolute values and percentages) in the cover than in the lake water. Volvocales were also more abundant during the ablation phase when this algal group dominated completely the assemblages in the meltwater pools on top of the ice and snow cover with values of up to $1.7 \times 10^{6} \mu^{3} \mathrm{ml}^{-1}$ in May 1997.

The planktonic biomass ranges are summarized in Table 4. Lake water microbial assemblages were dominated by algae that ranged between 55 and $98 \%$ (average $72 \%$ ) of total microbial

of the winter cover growth period in 1997. Ciliate assemblages were dominated by Halteria grandinella. Paramecium cf. putrinum, Askenasia sp. and some non-identified species were occasionally of some significance. Prostomatida were highly abundant in a few slush samples.

The distribution of chl a content in the slush layers and the water column was similar over both years studied (Fig. 2). In the lake water, values were initially biomass. In the winter cover, the range of variation was higher and phytoplankton represented between 13 and $98 \%$ (average $53 \%$ ) of total microbial biomass. Heterotrophic biomass was dominated by bacteria, which represented on average $>80 \%$ of the heterotrophic biomass in both lake water and slush assemblages. For all microbial components, biomass ranges and averages were larger in the slush layers than in the lake water (Table 4). 
Table 3. Range of the biovolumes in $10^{3} \mu^{3} \mathrm{ml}^{-1}$ (Max. = maximum; Min. $=$ minimum) and average of the percentage of the total phytoplankton biovolume (\%Avg.), observed for the main algal groups in slush and lake water assemblages during the winter of 1997 and 1998. Data of surface meltwater pools were not considered. The period in which the group reached maximum biovolume is also indicated

\begin{tabular}{|lrlrrlrl|}
\hline & \multicolumn{3}{l}{$\begin{array}{l}\text { Cover } \\
\text { Max. }\end{array}$} & Min. \%Avg. & Max. & $\begin{array}{l}\text { Lake } \\
\text { Min. \%Avg. }\end{array}$ & $\begin{array}{c}\text { Period of } \\
\text { max.: }\end{array}$ \\
\hline Diatoms & 55 & 0 & 8 & 237 & 0 & 44 & Formation \\
Chrysophytes & 223 & 0.4 & 27 & 301 & 0.6 & 22 & Growth \\
Cryptophytes & 36 & 0 & 9 & 28 & 0 & 5 & Growth \\
Volvocales & 81 & 0 & 6 & 122 & 0 & 7 & Ablation \\
Dinoflagellates & 604 & 0 & 50 & 79 & 2 & 30 & Ablation \\
\hline
\end{tabular}

Table 4 . Range (Max. = maximum; Min. = minimum) and average (Avg.) of microbial groups biomass $\left(\mu \mathrm{C} \mathrm{Cl}^{-1}\right)$ for the winter cover and the lake water assemblages measured during the winter of 1997 and 1998. Pools assemblages were not considered. $\mathrm{N}=$ number of samples with data available

\begin{tabular}{|lrlrlrrrr|}
\hline & \multicolumn{4}{c}{ Cover } & \multicolumn{5}{c|}{ Lake } \\
& Max. & Min. & Avg. & N & Max. & Min. & Avg. & N \\
\hline $\begin{array}{l}\text { Phytoplankton } \\
\text { Heterotrophic }\end{array}$ & 124 & 1.3 & 23.9 & 34 & 61.7 & 3.0 & 21.9 & 23 \\
$\begin{array}{l}\text { flagellates } \\
\text { Ciliates }\end{array}$ & 15.5 & 0.01 & 0.7 & 34 & 1.4 & 0 & 0.4 & 23 \\
Bacteria & 8.8 & 0 & 1.0 & 34 & 2.1 & 0 & 0.6 & 23 \\
& 17.6 & 1.1 & 9.3 & 27 & 10.5 & 0.9 & 6.0 & 12 \\
\hline
\end{tabular}

\section{Vertical and temporal changes of microbial assemblages}

The vertical composition of microbial assemblages changed considerably between successive slush lay- ers. Layers separated by only a few $\mathrm{cm}$ of white ice showed a quite different phytoplankton composition (see Fig. 3), indicating the importance of the physical isolation of the slush layers for the development of the communities. To study the points of main divergence in vertically contiguous samples, we calculated the distance between samples based on assemblage composition (using the similarity coefficient of Steinhaus transformed to distance, D) related to the physical distance (in $\mathrm{cm}$ ) between samples $\left(D \mathrm{~cm}^{-1}\right)$. For each sampling day, we obtained a matrix of distances between sequential slush layers, between slush layers and lake water surface, and between sequential depths in the water column. The $D \mathrm{~cm}^{-1}$ values between slush layers were always higher than within and between lake water samples (Fig. 4). Vertical changes in the water column communities were always small, and only at the beginning of the growth period in the winter of 1998 , did the $D \mathrm{~cm}^{-1}$ between lake water surface and deeper slush layers become larger than changes within the cover. When the winter cover reached its maximum thickness, the differences between some slush layer assemblages became larger (Fig. 4). In the water column, temporal changes of microbial assemblages were
19-March-97

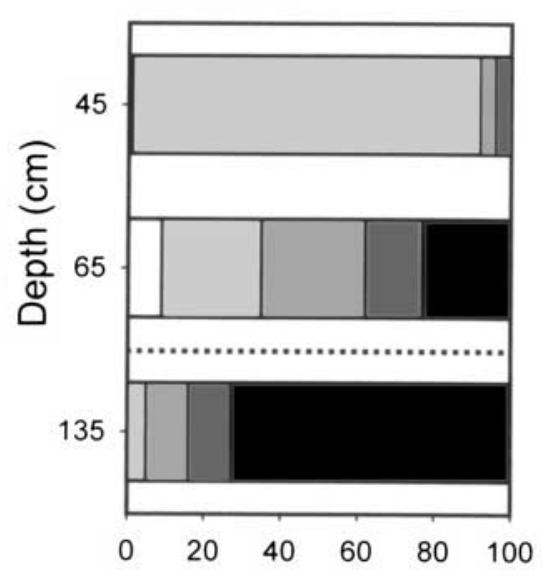

17-April-97

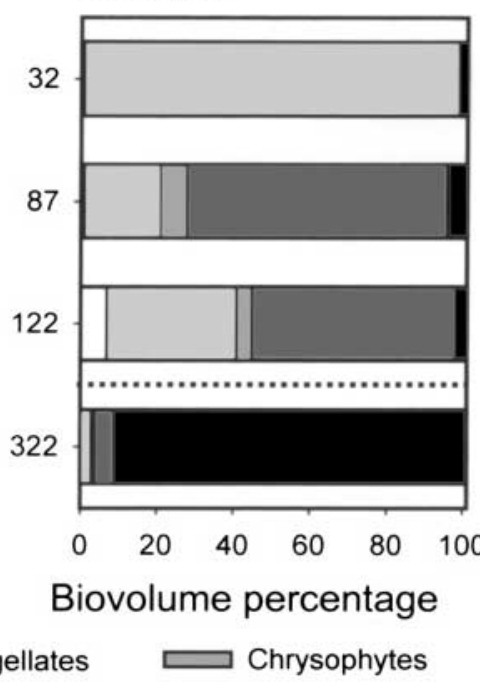

1-May-97

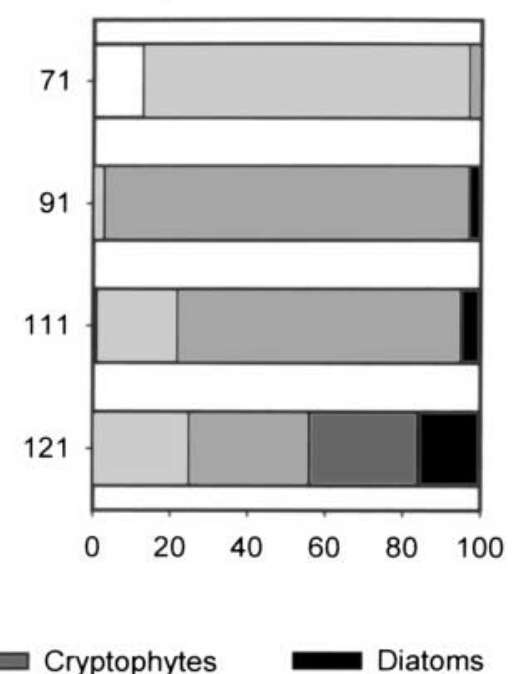

Fig. 3. Phytoplankton composition (percentage of biovolume) of the main taxonomic groups observed in slush layers of the winter cover and lake water for various dates of the growth period of 1997. Depth of the layer sampled from cover surface. The dotted line separates cover and lake water samples 

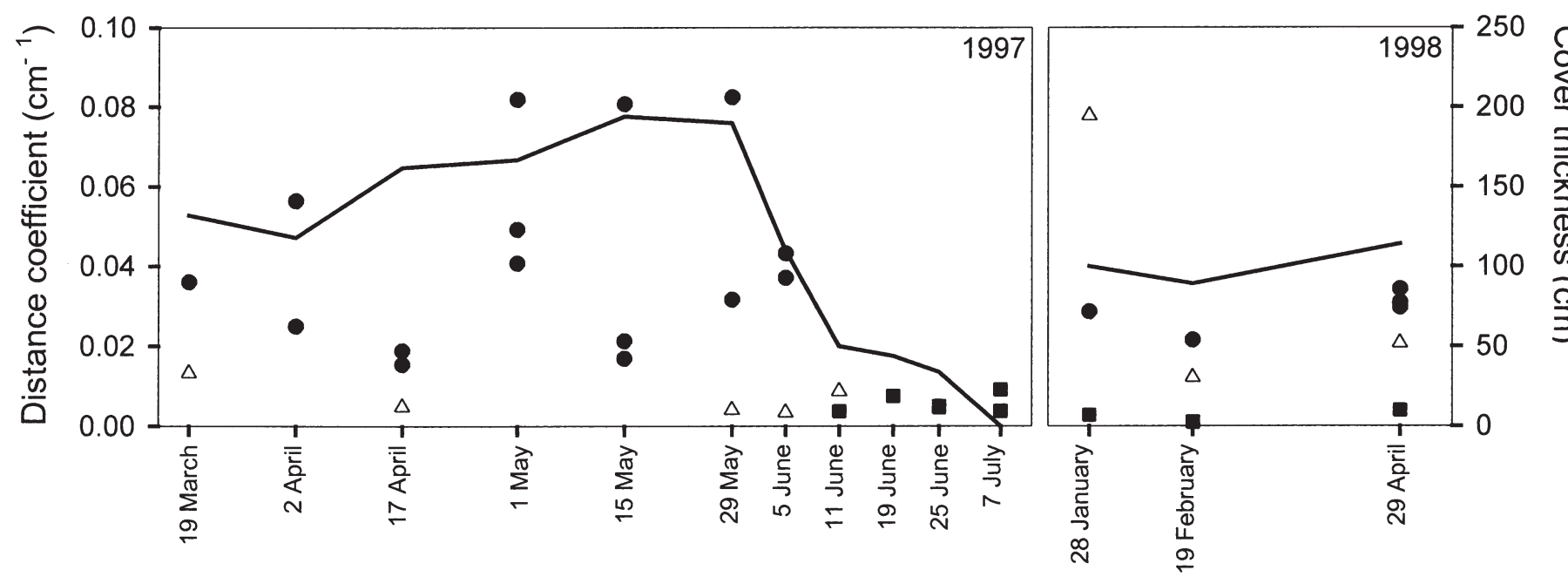

Fig. 4. Distance coefficients between spatially sequential samples based on the composition of microbial assemblages and normalized to the physical distance between samples $\left(D \mathrm{~cm}^{-1}\right)$ in Spring 1997 and Winter 1998 (left $y$-axis). (๑) Distance between successive slush layer samples; $(\Delta)$ distance between the deepest slush layer and surface lake water samples; $(\square)$ distance between lake water samples at different depths. The black line indicates the thickness of the winter cover (right $y$-axis). For instance, on 17 April the cover had 3 slush layers (at 32, 87 and $122 \mathrm{~cm}$ depth) and lake water was sampled at $3 \mathrm{~m}$ depth; the 2 black circles for this date correspond to the distance between the slush samples at 32 to 87 and 87 to $122 \mathrm{~cm}$ and the triangle indicates the distance between the slush at $122 \mathrm{~cm}$ and the lake water samples

evaluated by the distance between samples based on species composition $(D)$ related to the period of time between successive sampling dates (days). This method could not be applied in slush layers because it is not possible to follow the same slush layer over time. The range of change observed at different depths (Table 5) decreased with depth, whereby we observed 2 zones: the upper part of the water column $(0$ to $1 \mathrm{~m}$ depth), in which the changes of assemblages were high; and the deeper part ( 3 to $4 \mathrm{~m}$ ) that showed slight changes of species assemblages over time.

\section{Relationship between winter cover and lake water assemblages}

To evaluate the relationship of microbial assemblages between slush layers and lake water, a corre-

Table 5. Range and average of the distance between samples based on assemblage composition $(D)$ related to the period of time passed between samples (days), calculated for different depths of the water column during the winter period of 1997 and 1998

\begin{tabular}{|lccc|}
\hline \multirow{2}{*}{ Depth $(\mathrm{m})$} & \multicolumn{3}{c|}{ Temporal change $\left(D \mathrm{~d}^{-1}\right)$} \\
& Max. & Min. & Avg. \\
\hline 0 & 0.160 & 0.102 & 0.131 \\
1 & 0.148 & 0.119 & 0.134 \\
3 & 0.093 & 0.017 & 0.067 \\
4 & 0.051 & 0.006 & 0.031 \\
\hline
\end{tabular}

spondence analysis was performed with the whole data set, 1997 and 1998 samples, 34 from slush and 23 from the water column. The Axis 1 eigenvalue was 0.18 , and it explained $15 \%$ of species variability, mainly reflecting the differences between cover and lake water assemblages (Fig. 5). Samples from 0 and $1 \mathrm{~m}$ depth had an intermediate position between the slush layers and deeper lake water samples, indicating a transition between both clusters. Species associated primarily with the slush layers included some volvocales (Chlamydomonas nivalis and Chlamydomonas sp.) and the ciliates Trachelius ovum and Paramecium cf. putrinum; whereas lake water samples were mainly characterized by the presence of diatoms, Cosmarium sp., Amphidinium sp. and the ciliate Askenasia sp. There is an evident temporal pattern in the samples ordination (Fig. 5). Samples from the ablation period showed highest loads on the first axis, indicating that cover microbial assemblages during the ablation period were highly different from lake water assemblages and form a specific community typical of this habitat.

\section{DISCUSSION}

This study shows that the temporal changes of microbial assemblages in the slush layers of the winter cover of Gossenköllesee followed the same pattern that has been described in Lake Redó in the Pyrenees (Felip et al. 1999). In both lakes, microbial biomass and 


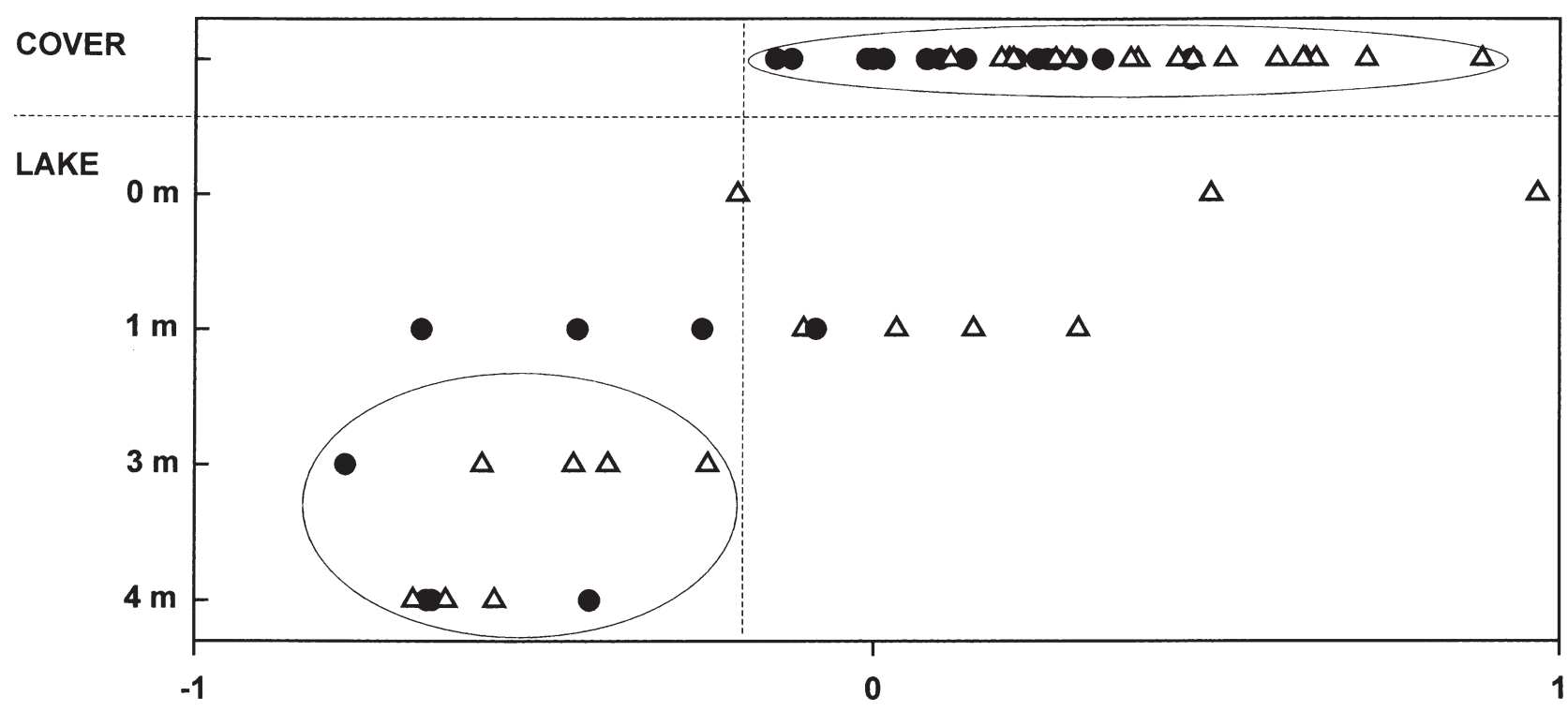

Fig. 5. Results of the correspondence analysis performed with species biovolumes for the whole data set (1997 and 1998). Values of Axis 1 sample scores against slush layer (cover), and lake water samples (lake) at the corresponding depth. (•) Growth period of the winter cover; $(\Delta)$ ablation period

composition reflected the changes in the physical transformations of the winter cover structure. Temporal variability in the physical structure and chemical composition of the ice and snow cover are similar in both lakes and for the different winter periods studied (Felip et al. 1999, A. Wille unpubl. data). During the formation period, i.e. at the beginning of the development of slush layers in early winter, the microbial biomass in the water column is high and non-flagellated phytoplanktonic groups - diatoms in Gossenköllesee and chlorococcales in Lake Redó - which are typical of the autumn communities, dominate the lake assemblages (Tables $2 \& 3$, Fig. 2). At this time, cover assemblages were not properly established. During the growth period, broadly from ca. January to midApril (Pyrenees) or from January to mid-May (Alps) microbial assemblages of the ice and snow cover are characterized by the influence of lake water organisms. Surface lake water that floods the cover as a result of the hydrostatic adjustment after each snowfall acts as an inoculum for the slush layers (Figs. 1, 2 \& 5). Potential mixotrophic (mainly chrysophytes and cryptophytes) and heterotrophic flagellated species grow and peak in different slush layers over time (Tables 2 \& 3). Throughout the winter cover growth period the assemblages become poorer in terms of microorganisms density and diversity, reaching minimum values at the end of this period (Figs. 1 \& 2). We should not forget that the growth period of the winter cover results in an increased separation of the lake from the outer world, and that during this period less than $0.1 \%$ of the incident light may reach the lake water (Catalan 1992). The winter cover growth period represents thus a transition from autotrophic to heterotrophic conditions for the lake water and the deeper layers of the cover. The ablation phase is characterized by the input of organisms from the catchment and a high rate of temporal change. Initially, microbial assemblages of the ice and snow cover are dominated by a dinoflagellate species, identified as Gymnodinium sp. in Gossenköllesee (Tables 2 \& 3), and as Gymnodinium cnecoides in Lake Redó (see Fig. 5 in Felip et al. 1999). At the end of the ablation period, we found some large ciliates that are typical for benthic sites (Foissner et al. 1999) such as Lacrymaria sp. and Dileptus sp. in Lake Redó, and Trachelius ovum and Paramecium putrinum in Gossenköllesee (Table 2). In addition, large red volvocales (Chlamydomonas spp., Pteromonas sp.) appear in the upper cover layers and surface melting pools of both lakes (Tables 2 \& 3). Dileptus and Trachelius are taxonomically closely related (Foissner et al. 1995). During the ablation periods of 1999 and 2000, we also found Lacrymaria sp. in the slush layers of Gossenköllesee (unpubl. data).

It is interesting that while during the growth period slush assemblages differ between both lakes, the composition of cover assemblages during the ablation period is highly similar in both lakes. The differences in the winter cover microbial communities between lakes during the growth period are obviously due to the different composition of the initial pioneer (plankton) communities, and to the nature of the ice and 


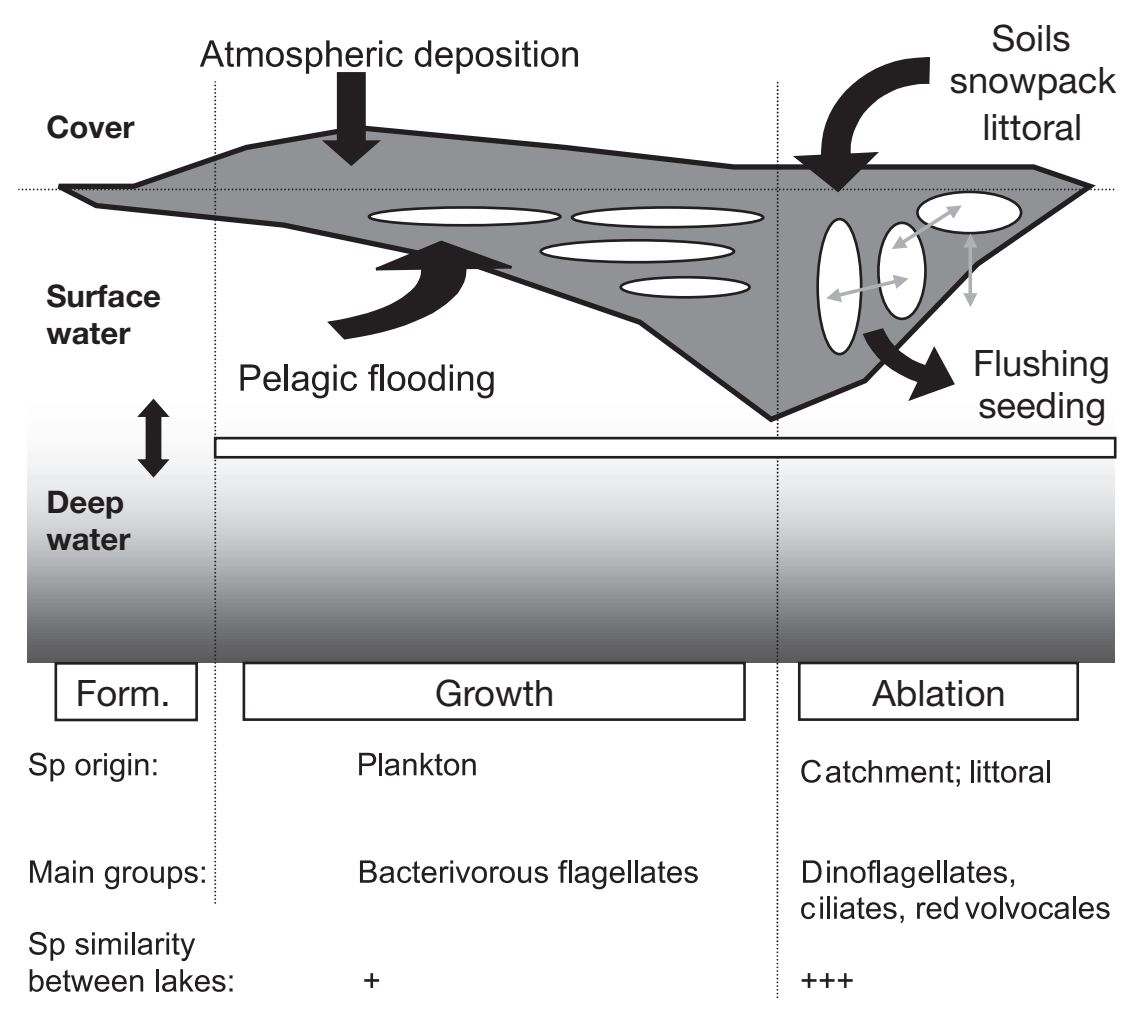

Fig. 6. Summary of the main driving forces on microbial assemblages and physicochemical structures in slush layers and their interactions with the water column. Main features of cover assemblages for the different periods are also indicated. $\mathrm{Sp}=$ species

snow cover itself. The physical isolation between slush layers largely determines the variety of microbial assemblages, which show maximum differences when the thickness of the cover was highest (Fig. 4). The assemblages during the ablation period are much less influenced by or completely isolated from lake water communities (Fig. 5), but closely related to the microbial communities in the snowpack and soils of the catchment. Snow isolates the soil surface and allows it to thaw before the snow melts (Sommerfeld et al. 1993, Brooks et al. 1996), leading to high levels of heterotrophic activity at the soil surface (Brooks et al. 1996, 1997, 1998). It is well known that populations of algae, mainly chlorophytes, inhabit snow (Kol 1968, Hoham 1980). Snow algal assemblages are similar worldwide and Chlamydomonas nivalis is the most ubiquitous species (Hoham \& Blinn 1979, Thomas \& Broady 1997 , Duval et al. 1999). The ecology of snow microorganisms appears to be related to the water content of the snow as a milieu for the transport of nutrients, and a prerequisite for the growth and mobility of algae (Mosser et al. 1977, Kawecka \& Drake 1978, Jones 1999). Circulation of melt water from snowpack and soil surface to and throughout the cover of the lake seems to represent the main colonization mechanism of microorganisms during the ablation phase, which is followed by high growth rates in the slush (Felip et al. unpubl.). The similarity of Protozoa living in catchment soils or littoral sediments, and of snow algae may explain the close correspondence between slush assemblages in the winter cover of morphologically such diverse and geographically distant lakes of the Alps and the Pyrenees during the ablation phase.

Finally, in reference to the interactions between the winter cover and the lake water, we observed that the cover appeared to be more dynamic (Figs. 3 \& 4), and sporadically richer in organisms density and biomass (Tables $2 \& 4$, Fig. 1) than the water column. Similar observations in arctic marine ice communities found that variability of phytoplankton distribution, species diversity and cell numbers were higher in the ice cover than in the water column (Hsiao 1992). The use of molecular biological methods to identify bacterial populations showed that abundance of filamentous bacteria and some bacterial phylotypes clearly differed between slush layers and water column (Alfreider et al. 1996, Pernthaler et al. 2000). The mutual influence between lake water and cover assemblages affects only the upper 1 to $2 \mathrm{~m}$ of the water column (Fig. 5) which show a high rate of temporal change (Table 5). Microbial composition in deeper layers was poorly related to cover assemblages and temporal changes were slow (Table 5, Fig. 5). Fig. 6 summarizes the main driving forces and trends of the slush and lake water relationships. During the growth period, it is the surface water that floods the cover while during ablation, meltwater influences only the uppermost layers of the water column and is rapidly flushed out (Gunn \& Keller 1985, Adams \& Allan 1987). Our study thus supports the explanation of the 'chloride paradox' observed in the Alps and the Pyrenees by Camarero et al. (1995). They found that chloride concentrations in lakes were on average smaller than in precipitation-notwithstanding large differences in chloride deposition between both regions - and attributed this paradox to partial mixing and surface flushing of the water layer in spring. 


\section{CONCLUSIONS}

This study confirms the importance of the physical transformation of the lake cover in shaping microbial assemblages and emphasizes a general pattern for the winter cover dynamics of alpine lakes which extends, beyond physico-chemical similarities, to the composition of microbial communities. We believe that this pattern has wider significance and could be applied to all lakes in snowy regions.

Winter plankton dynamics in high mountain lakes are obviously affected by the occurrence of the ice and snow cover, which changes physico-chemical characteristics of the water column. While lake plankton has a dominant influence on microbial assemblages in the cover during the phase of formation and growth, the catchment plays a major role in shaping this specific environment with its assemblages during the ablation and snowmelt period. Shortly before the final disappearance of the winter cover, slush assemblages may exert a seeding effect on lake water communities. This suggests a reversal of the transport directions between lake water and winter cover at the beginning of the ablation period. In both cases, however, only a small part of the water column seems to be involved. What has become evident from several studies is that the winter cover of alpine lakes represents a particular habitat of its own, with specific structures, dynamics and communities, and intermittently colonized by organisms resulting from atmospheric transport, lake water and catchment. These findings show that 2 separated systems (the winter cover and the water column) coexist in 1 lake for about $6 \mathrm{mo} \mathrm{yr}^{-1}$. Additionally, they do influence each other, but only to a limited degree. The border line between both systems neither coincides with the ice-water interface nor includes the whole water body. The winter cover seems also to bridge the lake-catchment interface - at least during the ablation period. In spite of the weak inverse stratification of the water column during winter, our data indicate only a partial mixing during the period of highest flushing rates (thawing). Interestingly, lakes behave more individualistically than their catchments as shown by the greater similarity of the winter covers between Alps and Pyrenees during the ablation phase, influenced by organisms and processes in the catchment, than during the previous, plankton-dominated period of build-up and growth.

Acknowledgements. We wish to thank Josef Franzoi and Werner Müller for thorough chemical analysis, Markus Petter for providing bacterial data, Frederic Bartumeus for assistance in similarity coefficient calculations and also valuable suggestions, and Jordi Catalan for introducing us to the beauty of ice and snow cover on high mountain lakes. This study was supported by the Austrian Science Foundation
(P14201-BIO), by the European Commission (MOLAR ENV4CT95-0007), and by a post-doctoral grant to M.F. from the European Commission (Nr. ENV4-CT98-5099).

\section{LITERATURE CITED}

Adams WP, Allan C (1987) Aspects of the chemistry of ice, notably snow, on lakes. In: Jones HG, Orville-Thomas WJ (eds) Seasonal snowcovers: physics, chemistry, hydrology. Reidel Publishing Company, Dordrecht, p 393-466

Alfreider A, Pernthaler J, Amann R, Sattler B, Wille A, Psenner R (1996) Community analysis of the bacterial assemblages in the winter cover and pelagic layers of a high mountain lake by in situ hybridization. Appl Environ Microbiol 62:2138-2144

Borsheim KY, Bratbak G (1987) Cell volume to carbon conversion factors for a bacterivorous Monas sp. enriched from seawater. Mar Ecol Prog Ser 36:171-175

Brooks PD, Williams MW, Schmidt SK (1996) Microbial activity under alpine snow packs, Niwot Ridge, CO. Biogeochemistry 32:93-113

Brooks PD, Schmidt SK, Williams MW (1997) Winter production of $\mathrm{CO}_{2}$ and $\mathrm{N}_{2} \mathrm{O}$ from alpine tundra: environmental controls and relationship to inter-system $\mathrm{C}$ and $\mathrm{N}$ fluxes. Oecologia 110:403-413

Brooks PD, Williams MW, Schmidt SK (1998) Inorganic nitrogen and microbial biomass dynamics before and during snowmelt. Biogeochemistry 43:1-15

Camarero L (1994) Regional chemistry of the Pyrenean lakes: bases for the use of mountain lakes as monitoring systems of global acidification. PhD thesis, University of Barcelona

Camarero L, Catalan J, Boggero A, Marchetto A, Mosello R, Psenner R (1995) Acidification in high mountain lakes in central, southwest and southeast Europe (Alps, Pyrenees, Pirin). Limnologica 25:141-156

Catalan J (1989) The winter cover of a high-mountain Mediterranean lake (Estany Redó, Pyrenees). Water Resour Res 25:519-527

Catalan J (1992) Evolution of dissolved and particulate matter during the ice-covered period in a deep, high mountain lake. Can J Fish Aquat Sci 49:945-955

Duval B, Duval E, Hoham RW (1999) Snow algae of the Sierra Nevada, Spain, and High Atlas mountains of Morocco. Int Microbiol 2:39-42

Eppacher T (1966) Umweltfaktoren und Lebewelt im Pelagial des Gossenköllesees (Kühtai, Stubaier Alpen, 2.413 m). $\mathrm{PhD}$ thesis, University of Innsbruck

Felip M, Sattler B, Psenner R, Catalan J (1995) Highly active microbial communities in the ice and snow cover of high mountain lakes. Appl Environ Microbiol 61:2394-2401

Felip M, Camarero L, Catalan J (1999) Temporal changes of microbial assemblages in the ice and snow cover of a high mountain lake. Limnol Oceanogr 44:973-987

Foissner W, Berger H, Blatterer H, Kohmann F (1995) Taxonomische und ökologische Revision der Ciliaten des Saprobiensystems. Band IV. Bayrisches Landesamt für Wasserwirtschaft, Munich

Foissner W, Berger H, Schaumburg J (1999) Identification and ecology of limnetic plankton ciliates. Bayrisches Landesamt für Wasserwirtschaft, Munich

Gunn JM, Keller W (1985) Effects of ice and snow cover on the chemistry of nearshore lake water during spring melt. Ann Glaciol 7:208-212

Hoham RW (1980) Unicellular chlorophytes — snow algae. In: Cox ER (ed) Phytoflagellates. Elsevier Scientific Publishers, New York, p 61-84 
Hoham RW, Blinn DW (1979) Distribution of cryophilic algae in an arid region, the American Southwest. Phycologia 1: 133-145

Hsiao SIC (1992) Dynamics of ice algae and phytoplankton in Frobisher Bay. Polar Biol 12:645-651

Jeffrey SW, Humphrey GF (1975) New spectrophotometric equations for determining chlorophyll $a, b, c 1$ and $c 2$ in higher plants, algae and natural phytoplankton. Biochem Physiol Pflanz 167:191-194

Jones HG (1999) The ecology of snow-covered systems: a brief overview of nutrient cycling and life in the cold. Hydrol Processes 13:2135-2147

Kawecka B, Drake BG (1978) Biology and ecology of snow algae 1. The sexual reproduction of Chlamydomonas nivalis (Bauer) Wille. Acta Hydrobiol 2:111-116

Kol E (1968) Kryobiologie. Biologie und Limnologie des Schnees und Eises, I. Kryovegetation. E. Die Binnengewässer. Band XXIV. Schweizerbartsche Verlagsbuchhandlung, Stuttgart

Legendre P, Legendre L (1998) Numerical ecology. Developments in environmental modeling 20. Elsevier Scientific Publishers, Amsterdam

Loferer-Krößbacher M, Klima J, Psenner R (1998) Determination of bacterial cell dry mass by transmission electron microscopy and densiometric image analysis. Appl Environ Microbiol 64:688-694

Margalef R (1983) Limnología. Omega, Barcelona

Mosser JL, Mosser AG, Brock TD (1977) Photosynthesis in the snow: the alga Chlamydomonas nivalis (Chlorophyceae). J Phycol 13:22-27

Müller H, Geller W (1993) Maximum growth rates of aquatic ciliates protozoa: the dependence on body size and temperature reconsidered. Arch Hydrobiol 126:315-327

Mullin MM, Sloan PR, Eppley RW (1996) Relationship between carbon content, cell volume, and area in phytoplankton. Limnol Oceanogr 11:307-311

Norland S (1993) The relationship between biomass and volume of bacteria. In: Kemp PF, Sherr BF, Sherr EB, Cole JJ (eds) Handbook of methods in aquatic microbial ecology. Lewis Publishers, Boca Raton, p 303-307

Pernthaler J, Wille A, Petter M, Sattler B, Psenner R, Glöckner FO, Amann R (2000) Bacterial community structure in the plankton and winter cover of a high mountain lake, Gossenköllesee 2417 m.a.s.l, Tyrol, Austria. Int Symp High Mountain Lakes and Streams, Innsbruck

Porter KG, Feig YS (1980) The use of DAPI for identifying and counting aquatic microflora. Limnol Oceanogr 25:943-948

Priscu JC, Fritsen CH, Adams EE, Giovannoni SJ and 6 others (1998) Perennial Antarctic lake ice: an oasis for life in a polar desert. Science 280:2095-2098

Editorial responsibility: Karel Šimek,

České Budějovice, Czech Republic
Psenner R, Sattler B (1998) Life at the freezing point. Science 280:2073-2074

Psenner R, Sattler B, Wille A, Fritsen CH, Priscu JC, Felip M, Catalan J (1999) Lake ice microbial communities in alpine and antarctic lakes. In: Margesin R, Schinner F (eds) Cold adapted organisms. Ecology, physiology, enzymology and molecular biology. Springer-Verlag, Heidelberg, p 17-31

Reynolds CS (1984) The ecology of freshwater phytoplankton. Cambridge University Press, Cambridge

Sommaruga R, Psenner R (1997) Ultraviolet radiation in a high mountain lake of the Austrian Alps: air and underwater measurements. Photochem Photobiol 65:957-963

Sommerfeld RA, Mosier AR, Musselman RC (1993) $\mathrm{CO}_{2}, \mathrm{CH}_{4}$ and $\mathrm{N}_{2} \mathrm{O}$ flux through a Wyoming snowpack. Nature 361: $140-143$

Sournia A (1978) Phytoplankton manual. UNESCO, Paris

Spaulding SA, Ward JV, Baron J (1993) Winter phytoplankton dynamics in a subalpine lake, Colorado, U.S.A. Arch Hydrobiol 129(2):179-198

Sullivan CW, Palmisano AC (1984) Sea ice microbial communities: distribution, abundance, and diversity of ice bacteria in McMurdo Sound, Antarctica, in 1980. Appl Environ Microbiol 47:788-795

ter Braak CJF (1995) Ordination. In: Jongman RHG, ter Braak CJF, Van Tongeren OFR (eds) Data analysis in community and landscape ecology. Cambridge University Press, Cambridge, p 91-165

Thies H, Nickus U, Arnold C, Schnegg R, Psenner R (2000) Biogeochemistry of a high mountain lake in the Austrian Alps. Verh Int Ver Limnol 27:517-520

Thomas WH, Broady PA (1997) Distribution of coloured snow and associated algal genera in New Zealand. NZ J Bot 35: 113-117

Wharton RA, McKay CP, Glow GD, Andersen DT (1993) Perennial ice covers and their influence on Antarctic lake ecosystems. In: Green WJ, Friedmann EI (eds) Physical and biogeochemical processes in Antarctic lakes, Vol 59. Antarctic Research Series. American Geophysical Union, Washington, DC, p 53-70

Wille A (1996) Lake ice microbial communities-LIMCO Physikalisch-chemische und mikrobiologische Untersuchung der Winterdecke des Gossenköllesees (2.417 m, Kühtai, Tirol). MSc thesis, University of Innsbruck

Wille A, Sonntag B, Sattler B, Psenner R (1999) Abundance, biomass and size structure of the microbial assemblage in the high mountain lake Gossenköllesee (Tyrol, Austria) during the ice-free period. J Limnol 58:117-126

Wille A, Sattler B, Psenner R (2000) Lake ice microbial communities (LIMCO)-biology of a periodic ecotone. Verh Int Ver Limnol 27:532

Submitted: November 6, 2001; Accepted: July 8, 2002

Proofs received from author(s): September 3, 2002 